\title{
The Effect of Principal Leadership and Internal Communication on Teacher Performance in Indonesia
}

\author{
Sabar Narimo, Dhany Efita Sari", Diana Ofintan, Surya Jatmika \\ Department of Accounting Education, Universitas Muhammadiyah Surakarta, Indonesia
}

Received August 3, 2020; Revised November 19, 2020; Accepted November 29, 2020

\section{Cite This Paper in the following Citation Styles}

(a): [1] Sabar Narimo, Dhany Efita Sari, Diana Ofintan, Surya Jatmika, "The Effect of Principal Leadership and Internal Communication on Teacher Performance in Indonesia," Universal Journal of Educational Research, Vol. 8, No. 12A, pp. 7864-7869, 2020. DOI: 10.13189/ujer.2020.082575.

(b): Sabar Narimo, Dhany Efita Sari, Diana Ofintan, Surya Jatmika (2020). The Effect of Principal Leadership and Internal Communication on Teacher Performance in Indonesia. Universal Journal of Educational Research, 8(12A), 7864-7869. DOI: 10.13189/ujer.2020.082575.

Copyright $\odot 2020$ by authors, all rights reserved. Authors agree that this article remains permanently open access under the terms of the Creative Commons Attribution License 4.0 International License

\begin{abstract}
This research aimed to 1) investigate the effect of principal leadership based on teacher perception on teacher performance, 2) investigate the effect of internal communication between principal and teacher on teacher performance, and 3) investigate the effect of principal leadership and internal communication on teacher performance. Causal comparative method was performed in this research. 110 teachers from private high schools in Indonesia were the population in this study. Questionnaires were used to collect data for all variables. T-test and multiple regressions were performed to analysis hypotheses in this study. Results indicated that principal leadership has a positive effect and significantly correlates with teacher performance. Also, internal communication between principal and teachers has a positive effect and significantly correlates with teacher performance. In addition, principal leadership based on teacher perception and internal communication has a positive effect on teacher performance. Therefore, it is essential to do further research about another factors influencing teacher performance.
\end{abstract}

Keywords School Principal Leadership, Teacher Performance, Internal Communication, Private High Schools

\section{Introduction}

Teachers are professional educators who have the task of educating, teaching, guiding, directing, training, assessing, and evaluating students in formal education, basic education, and secondary education. Therefore, tasks that must be performed by teachers, making them as the center of attention improve the quality of education. The quality of education will be adequate if the teachers' performance is adequate.

However, the ability of teachers to improve their performance does not always develop properly. In addition, teachers' performance is still relatively poor. It is caused by an influence from other factors, such as within teacher's personality or outside the teacher's personality.

Mahgoub \& Elyas stated that development of teacher performance was in the low level, because they had not been able to interact with students and their teaching methods were still using conventional ones [2]. Therefore, teachers must be encouraged with teaching aids that can assist in learning such as communication skills, discussion and dialogue, problem-solving, role-play, discovery, and brainstorming.

Research showed that vocational high school teachers had low pedagogic and professional performance. It was influenced by factors of expectations about reward, teachers' abilities, encouragement, internal and external rewards, and low job satisfaction. Besides, there were also found problems and constraints on teachers, 1) quality, quantity, and distribution, 2) welfare, 3) teacher management, 4) teacher appreciation, and 5) teacher education [3].

Findings showed teacher performance was low due to teacher expertise in elementary, junior high, high school 
and vocational high school levels in mastering material by $27.67 \%$ of the target. This percentage is still below the average of minimum of $75 \%$. It means, $40 \%$ of middle and high school teachers taught outside their expertise. As a result, there are still many teachers who teach without preparation and are monotonous. According to Supardi [10], teacher performance is an effort made by teacher in teaching and learning activities to improve students' learning outcomes. In line teachers must possess four competencies, namely professional, personality, pedagogic, and social.

In this case, the expertise possessed by teachers to carry out their duties is assessed from the mastery of competencies, teachers' ability in teaching, and the application of knowledge. Assessment of the teachers' ability to carry out their responsibilities is called Teacher Performance Assessment. Teacher performance assessment is the assessment of each teacher's assignment in rank, position, and career guidance.

Teacher performance assessment system aims to see 1) the level of teacher mastery, 2) the level of effectiveness and efficiency of teacher performance, 3) to provide a foundation for decision-making 4) to provide a foundation in the professional development program for teachers, 5) to guarantee teachers to carry out tasks and responsibilities, 6) to provide a system to improve teacher promotion and career path with other forms of appreciation [4]. Teacher performance assessment results vary due to several factors including work environment, individual teacher, and leadership. In the leadership factor, which is the principal leadership, as the principal must carry out the duties optimally and be able to lead the school in good direction and wisely, and the objectives can be achieved optimally to improve the quality of education in schools [5].

Nonetheless, the leadership of school principal depends on teacher because teachers are the pivotal elements in implementing education. Leadership is something that can influence other people to follow them as expected [6]. According to Syarifudin [7], principal leadership is the ability of a leader to persuade and convince subordinates that they are committed and enthusiastic to follow their leader. Moreover, there are misunderstandings and the unclear information obtained by teachers, which make it difficult for teachers to carry out the instructions given by the principal. The misunderstanding of these teachers is internal communication, so internal communication must be well-established. According to Ardana [8], internal communication is an exchange of information, both oral and written, or with communication tools within an organizational environment.

Based on the observations in private high school in Surakarta, Indonesia, the average of teacher performance level increased every year, but it was not significant. It was shown from the lack of encouragement from the school principal, the completion of less effective lesson plan. many students did not understand the explanation and had poor internal communication with their teachers. For these reasons, principals of this private high schools in Surakarta, Indonesia might have proper strategy to improve teacher performance, which is to carry out school principal leadership and internal communication.

The purpose of this study is to investigate: 1) the effect of principal leadership on teacher performance in private high school, 2) the effect internal communication on teacher performance, also, 3) the effect of principal leadership and internal communication on teacher performance in the private high school in Surakarta, Indonesia.

\section{Materials and Methods}

This is a causal comparative research using census design [9]. Population in this study is teachers in Muhammadiyah private high school which consisted of four schools, Muhammadiyah private high school number 1, Muhammadiyah private high school number 2, Muhammadiyah private high school number 6, and Special Program of Muhammadiyah private high school. By using saturation sampling, all of the population were used as respondents. It was 110 teachers for four schools. The population refers to opinion of [9], if part of the population is taken based on a certain amount, but if the population is close to 100 then all population can be taken as a sample.

The instruments in data collection consist of questionnaire and the preparation of previous questionnaires that had been tested on 20 teachers. The trial of the instruments was outside the scope of the Muhammadiyah Senior High School in Surakarta, Indonesia. The trial is used to test the validity and reliability of the data [10]. Data collection techniques used are questionnaire [11] and documentation [12]. The dependent variable of this study is teacher performance $(\mathrm{Y})$, while the independent variables are the principal leadership (X1) and internal communication (X2). As for the data presentation techniques in this study used tables [9]. Data analysis techniques used with data prerequisites are normality test, multicollinearity test [13], and linearity test, multiple regression analysis [14]. To test hypotheses, t-test and F-test performed [15], also determinant coefficient $\left(\mathrm{R}^{2}\right)$, effective contribution and relative contribution.

\section{Results and Discussions}

The result of the first prerequisite analysis is the normality test. The normality test aims to see whether the research sample data was normally distributed or not. In 
normal assumptions or not, it can be determined by comparing the significance number with the probability value $>0.05$ and the samples were 110, then it was normally distributed. It is shown in the table below.

Table 1. Summary of Data Normality Test Results

\begin{tabular}{ccccc}
\hline Variable & $\mathrm{N}$ & $\begin{array}{c}\text { Probability } \\
\text { of } \\
\text { Significance }\end{array}$ & $\begin{array}{c}\text { Error } \\
\text { Rate (a) }\end{array}$ & Conclusion \\
\hline $\begin{array}{c}\text { Principal } \\
\text { leadership }\end{array}$ & 110 & .287 & 0.05 & Normal \\
\hline $\begin{array}{c}\text { Internal } \\
\text { communication }\end{array}$ & 110 & .374 & 0.05 & Normal \\
\hline $\begin{array}{c}\text { Teacher } \\
\text { performance }\end{array}$ & 110 & 0.430 & 0.05 & Normal \\
\hline
\end{tabular}

Test was carried out using SPSS, then the three variables obtained significance $>0.05$, which means all variables were normally distributed.

The result of the second prerequisite analysis is the multicollinearity test. The purpose of this test is to see whether the regression model shows the correlation between the independent variables. A good regression model does not show correlation on the independent variable. To find out the occurrence of multicollinearity or not with a tolerance number $>0.1$ and VIF $<10$, it is concluded that there was no multicollinearity. The table is presented as below.

Table 2. The Calculation Results of Multicollinearity Test

\begin{tabular}{cccc}
\hline Variable & Tolerance & VIF & Information \\
\hline Principal leadership & 0.813 & 1.230 & $\begin{array}{c}\text { There is no } \\
\text { multicollinearity }\end{array}$ \\
\hline $\begin{array}{c}\text { Internal } \\
\text { communication }\end{array}$ & 0.813 & 1.230 & $\begin{array}{c}\text { There is no } \\
\text { multicollinearity }\end{array}$ \\
\hline
\end{tabular}

In the Table 2, it shows there was no multicollinearity.

The third test result in the analysis prerequisite test is the linearity test. This test aims to see whether both variables have a linearity or insignificance. It is presented in the Table 3.

Table 3. Calculations Results of Linearity Test

\begin{tabular}{cccc}
\hline Variable & Sign. & Error Rate & Information \\
\hline $\begin{array}{c}\text { Principal leadership } \\
\text { towards teacher } \\
\text { performance }\end{array}$ & 0.319 & 0.05 & Linear \\
\hline $\begin{array}{c}\text { Internal } \\
\text { communication of } \\
\text { teacher performance }\end{array}$ & .174 & 0.05 & Linear \\
\hline
\end{tabular}

The linearity test results above indicate that $\mathrm{p}>0.05$, which implies that the regression model of each variable has a linear or straight-line relationship.

The next test after the prerequisite tests have been met is multiple analysis. The analysis was carried out to find whether or not there was a joint influence of principal leadership and internal communication on teacher performance.
Table 4. Summary of the Results of the Multiple Linear Regression Test

\begin{tabular}{lccc}
\hline Variable & $\begin{array}{l}\text { Regression } \\
\text { Coefficient }\end{array}$ & T result & Sig. \\
\hline A constant & 73.803 & & \\
Principal Leadership & 0.707 & 7.028 & 0.000 \\
Internal communication & 0.314 & 2.925 & 0.007 \\
\hline F result & 31.228 & & \\
$\mathrm{R}^{2}$ & .369 & & \\
\hline
\end{tabular}

The above data obtained the equation $\mathrm{Y}=73.803+$ $0.707 \mathrm{X} 1+0.314 \mathrm{X} 2$. It determines that the principal leadership and internal communication variables together have a positive effect on the teacher performance variable or $\mathrm{Y}=\mathrm{a}$ positive value constant of 73.803. It can be determined that the principal leadership and internal communication variable are zero, the teacher performance variable value is 73.803 . Whereas 0.707 denotes that each increase in the value of the principal leadership variable by a point means that the principal leadership variable increases by 0.707 through the assumption of a fixed variable. The value of 0.314 indicates that each increase in the internal communication variable is one point, meaning that the internal communication variable has an increase of 0.314 through the assumption of a fixed variable.

Furthermore, testing the hypothesis through a partial test ( $\mathrm{t}$-test) and simultaneous test ( $\mathrm{F}$ test). $\mathrm{t}$-test was carried out to find the significant effect between the independent variable of the principal leadership and internal communication on the dependent variable, which is teacher performance. Then the hypothesis can be accepted or rejected.

$\mathrm{T}$ test results on the principal leadership variable (X1) can be seen $t>t$ table $(6.080>1.982)$ then Ho is rejected. Thus, there was a positive influence on the principal leadership on teacher performance, and therefore the first hypothesis is accepted. T-test results on the internal communication variable (X2) can be seen $t>t$ table $(2.925>1.982)$, then Ho is rejected. Hence, there was a positive effect of internal communication on teacher performance, and therefore the second hypothesis is accepted.

The F-test was used to find the influence of the principal leadership and internal communication simultaneously on teacher performance. F-test results can be seen $\mathrm{F}>\mathrm{F}$ table $(31.222>3.08)$, meaning $\mathrm{Ho}$ is rejected. So, there was a significant influence on the principal leadership and internal communication on teacher performance, which implies the hypothesis assumed is accepted. Then, the principal leadership and internal communication affected the performance of Private high school teachers in Surakarta, Indonesia.

The coefficient of determination $\left(\mathrm{R}^{2}\right)$ proves that the variation of the dependent variable can be shown as the independent variable in the model. The results of $R^{2}$ are from 0 to 1 . If $R^{2}$ is close to 1 , then it proves that the dependent variable can simultaneously be shown an independent variable. Likewise, if the number $\mathrm{R}^{2}$ is near 
to 0 , it means that the dependent variable cannot be shown as an independent variable. The results show the coefficient of determination $\left(\mathrm{R}^{2}\right)$ of 0.369 . The value of $\mathrm{R}^{2}$ on the principal leadership and internal communication variables influences the teacher's performance by $36.9 \%$, while the remaining $63.1 \%$ was influenced by other variables not examined.

The results of the research analysis show that the principal leadership and internal communication were jointly positive for the performance of Private high school teachers in Surakarta, Indonesia. This can be seen from the linear regression equation as follows $\mathrm{Y}=73.803+$ $0.707 \mathrm{X} 1+0.314 \mathrm{X} 2$. Based on this equation, it is known that the regression coefficient on each independent variable was positive, meaning that the principal leadership and internal communication variables together have a positive effect on the performance of Private high school teachers in Surakarta, Indonesia.

The first hypothesis test results determine that the regression direction coefficient of the principal leadership variable (X1) was 0.707 or positive, it explains that there was a positive influence of the principal leadership on teacher performance. Then, the significance test of the multiple linear regression coefficient for the principal leadership variable (X1) obtained $\mathrm{t}>\mathrm{t}$ table, which was $7.028>1.982$ and a significance value $<0.05$, namely 0.000 with a relative contribution of $83 \%$ and an effective contribution of $30.6 \%$. It concludes that the better the principal leadership, the higher the teacher performance.

Conversely, the lower the principal leadership, the lower the teacher performance. This is supported by theoretical studies and relevant researches. Principal leadership is a skill possessed by the leader as well as ownership of qualifications, positions, and appointments by the educational unit authorized to influence members to act following educational objectives [16]. In line with, there was a positive and significant influence of principal leadership on teacher performance [17]. Besides, Firmawati, Yusrizal, \& Usman state that there was a significant influence between the principal leadership on the teacher's performance by $35.8 \%$ [18].

The second hypothesis shows the regression coefficient of the internal communication variable (X2) of 0.314 or a positive value, so there was a positive influence of internal communication on teacher performance. Based on the t-test for internal communication variable (X2), it obtained $\mathrm{t}>\mathrm{t}$ table, which was $2.925>1.982$ and a significance value $<0.05$, namely 0.007 with a relative contribution of $17 \%$ and an effective contribution of $6.3 \%$. It concludes that that the better the internal communication, the higher the teacher performance, otherwise, the lower the internal communication, the lower the teacher performance.

The results of the study are consistent with the theories and relevant researches. According to Ardana [8], internal communication is the delivery or information exchange from the sender to the recipient, in written, oral, or use a communication tools in the organizational environment. This is in line with the results of research conducted by Jonathan [19] which state that there was a positive significant relationship between the communication of principals on teacher performance in secondary schools ( $\mathrm{r}$ $=0.603 ; \mathrm{p}>0.05)$. In line with, Wibowo said that there was a positive and significant effect of internal communication on teacher performance $\left(\mathrm{R}^{2}=0.081\right)$ [20].

The third hypothesis test on the significance test of multiple linear regression or $\mathrm{F}$ test found that the value of $\mathrm{F}>\mathrm{F}$ table was $31.222>3.08$ and the significance value $<$ 0.05 , which was 0.000 . It means the principal leadership and internal communication together have a positive effect on teacher performance. Based on the conclusion, it can be seen that the tendency of increasing in the combination of principal leadership and internal communication will be followed by an increase in teacher performance, whereas the tendency for a decrease in the combination of the principal leadership and internal communication variables will be followed by a decrease in teacher performance.

The third hypothesis is in line with the relevant theory. Teacher performance is a performance implemented by teachers to carry out their duties as educators [21]. This is following Supriadi \& Mutrofin [22] explained that the principal communication and leadership quality significantly affected teacher job satisfaction, with the regression equation of $\mathrm{Y}=13.90+0.30 \mathrm{X} 1+0.47 \mathrm{X} 2+$ e.

The coefficient of determination was obtained as much as 0.369 , which is the effect on the combination of principal leadership and internal communication variables on the teacher performance of Private high school in Surakarta, Indonesia by $36.9 \%$, while the rest was influenced by other variables.

The calculation results of the principal leadership variable contained a relative contribution of $83 \%$ and an effective contribution of $30.6 \%$. The internal communication variable contained a relative contribution of $17 \%$ and an effective contribution of $6.3 \%$. There was a comparison of the number of relative and effective contributions that the principal leadership variable had a dominant influence on teacher performance of Private high school in Surakarta, Indonesia compared to the internal communication variable.

\section{Conclusions}

Based on the purpose of the study, the examination of the hypothesis on the problems raised can be obtained as follows. The t-test result on the principal leadership variable t count was 6.080 , while the t-table was 1.982 so that the principal leadership had a significant influence on teacher performance with a significance of 0.05 , which 
was 0.000 with an effective contribution of $30.6 \%$ and a relative contribution of $83 \%$. it proves that there was an influence of principal leadership on the teacher performance of Private high school in Surakarta, Indonesia.

T-test result on the internal communication variable count was 2.925 , while the table was 1.982 , so internal communication had a significant influence on teacher performance with a significance of 0.05 , namely 0,000 with an effective contribution of $6.3 \%$ and a relative contribution of $17 \%$. It proves the influence of internal communication on the teacher performance of Private high schools in Surakarta, Indonesia

The results of the analysis of the F-test on $\mathrm{F}=31,228>$ $\mathrm{F}$ table $=3.08$, mean that $\mathrm{Ho}$ is rejected, so that simultaneously there was a significant influence of principal leadership (X1) and internal communication (X2) on teacher performance $(\mathrm{Y})$. These results prove that there was a significant influence of principal leadership and internal communication on the teacher performance of Private high schools in Surakarta, Indonesia. In this case, the hypothesis tested. The results of $\mathrm{R}^{2}$ or the coefficient of determination obtained $\mathrm{R}^{2}=0.369$, which means $36.9 \%$ of the principal leadership and internal communication affected teacher performance, while the remaining $63.1 \%$ was influenced by other variables that were not examined.

\section{Acknowledgments}

We would like to thank to Universitas Muhammadiyah Surakarta (UMS), Indonesia for this publication opportunity.

\section{REFERENCES}

[1] R. UU No 14 Tahun 2005, "Undang-undang Guru dan Dosen," Prod. Huk., 2005.

[2] S. Mahgoub, Yassir \& Elyas, "Development of Teacher Performance and its Impact on Enhancing on the Quality of the Educational Process Development of Teacher Performance and its Impact on Enhancing on the Quality of the Educational Process," Pensee J., vol. 76, no. 2, 2014.

[3] T. N. D. Harsono, Wahyudi and M. F. J. Syah, "Peran Pemerintah Dan Perguruan Tinggi Dalam Pembinaan Karier Guru Dalam Jabatan,” Semin. Nas. Pendidik., pp. 68-78, 2016.

[4] W. Damayanti, "Peningkatan Mutu Kinerja Guru Melalui Supervisi Akademik di SMK Negeri 1 Salatiga Menghadapi PKG 2016," J. Pendidik. Ilmu Sos., vol. 26, no. 1, pp. 80-86, 2016.

[5] H. D. N. Rohmah, W, Nurjanah A M, "Kepemimpinan Kewirausahaan Kepala Sekolah dalam Meningkatkan
Teacherpreneurship di Era MEA," Semin. Nas. Pendidik. PGSD UMS HDPGSDI Wil. Jawa, pp. 522-535, 2017.

[6] M. C. Asmawan, "Kepemimpinan transformasional kepala sekolah dalam mendukung gerakan literasi sekolah," $J$. Pendidik. dan Ilmu Sos., vol. 28, no. 1, pp. 46-57, 2018.

[7] T. Handayani and \& A. A. Rasyid, "PENGARUH KEPEMIMPINAN KEPALA SEKOLAH, MOTIVASI GURU, DAN BUDAYA ORGANISASI TERHADAP KINERJA GURU SMA NEGERI WONOSOBO," $J$. Akuntabilitas Manaj. Pendidik., 2015.

[8] R. R. Udayanto., I. W. Bagia., and N. N. Yulianthini., "Pengaruh Komunikasi Internal Dan Disiplin Kerja Terhadap Kinerja Karyawan Pada PT Coca-Cola," e-Journal Bisma Univ. Pendidik. Ganesha, ISSN 2312-5643, 2015.

[9] Harsono, Metode Penelitian Pendidikan, 1st ed. Sukoharjo: Jasmine, 2019.

[10] Supardi, Statistik Penelitian Pendidikan: Perhitungan, Penyajian, Penjelasan, Penafsiran, dan Kesimpulan, 1st ed. Depok: PT Rajagrafindo Persada, 2017.

[11] K. Komalasari, Pembelajaran Kontekstual Konsep dan Aplikasi. Bandung: PT. Refika Aditama, 2011.

[12] S. Arikunto, Dasar-dasar Evaluasi Pendidikan. Jakarta: Bumi Aksara, 2011.

[13] I. Ghozali, Aplikasi Analisis Multivariete Dengan Program IBM SPSS 23 (Edisi 8), 8th ed. Semarang: Badan Penerbit Universitas Diponegoro, 2016.

[14] Budiyono, Statistika untuk Penelitian Edisi ke - 2. Surakarta: Sebelas Maret University Press, 2011.

[15] Suharyadi \& Purwanto, Statistika untuk Ekonomi dan Keuangan Modern Edisi 2. Jakarta: Salemba Empa, 2011.

[16] G. \& I. Puspaningtyas, "Pengaruh Kepemimpinan Kepala Sekolah, Komunikasi Organisasi, Motivasi, dan Lingkungan Kerja terhadap Kinerja Guru di SMP Negeri 16 Semarang," Econ. Educ. Anal. J., vol. 4, no. 1, 2015.

[17] S. Purwoko, "Pengaruh kepemimpinan kepala sekolah, komitmen guru, disiplin kerja guru, dan budaya sekolah terhadap kinerja guru SMK," J. Akuntabilitas Manaj. Pendidik., 2018.

[18] Y. N. U. Firmawati, "PENGARUH KEPEMIMPINAN KEPALA SEKOLAH DAN MOTIVASI KERJA TERHADAP KINERJA GURU," J. Adm. Pendidik. Progr. Pascasarj. Unsyiah, 2018.

[19] N. Jonathan, "Principals' communication strategies and teachers' job performance in public secondary schools in ikenne local government area of ogun state," Int. J. Educ. Learn. Dev., vol. 5, no. 9, 2017.

[20] B. K. Wibowo, "PENGARUH KOMUNIKASI INTERNAL, MOTIVASI KERJA, DAN LOYALITAS TERHADAP KINERJA GURU SEKOLAH MENENGAH KEJURUAN NEGERI RUMPUN BISNIS SEKOTA SEMARANG," $J$. STIE Semarang, vol. 5, no. 2, 2013.

[21] S. Srinalia, "Faktor-Faktor Penyebab Rendahnya Kinerja Guru dan Korelasinya terhadap Pembinaan Siswa: Studi kasus di SMAN 1 Darul Imarah Aceh Besar," J. Ilm. Didakt., 
vol. 15 , no. 2 , p. $193,2015$.

[22] O. \& M. Supriadi, "The influence of principal's communication skills and quality of leadership on teachers' job satisfaction," J. Educ. Pract., vol. 8, no. 29, 2017. 